\title{
REVIEW
}

\section{Bench-to-bedside review: Bacterial pneumonia with influenza - pathogenesis and clinical implications}

\author{
Koenraad F van der Sluijs ${ }^{* 1}$, Tom van der Poll², René Lutter', Nicole P Juffermans ${ }^{3}$ and Marcus J Schultz ${ }^{3}$
}

\begin{abstract}
Seasonal and pandemic influenza are frequently complicated by bacterial infections, causing additional hospitalization and mortality. Secondary bacterial respiratory infection can be subdivided into combined viral/bacterial pneumonia and post-influenza pneumonia, which differ in their pathogenesis. During combined viral/bacterial infection, the virus, the bacterium and the host interact with each other. Post-influenza pneumonia may, at least in part, be due to resolution of inflammation caused by the primary viral infection. These mechanisms restore tissue homeostasis but greatly impair the host response against unrelated bacterial pathogens. In this review we summarize the underlying mechanisms leading to combined viral/bacterial infection or post-influenza pneumonia and highlight important considerations for effective treatment of bacterial pneumonia during and shortly after influenza.
\end{abstract}

\section{Background on influenza pandemics}

Influenza A virus is one of the most prevalent pathogens, causing respiratory illness every winter [1]. These influenza outbreaks are usually associated with mild symptoms, such as fever, headache, sore throat, sneezing and nausea, accompanied by decreased activity and food intake [2]. Nevertheless, influenza virus still accounts for 250,000 to 500,000 deaths each year and this number may increase due to the recently emerged H1N1 pandemic influenza strain [3].

Influenza virus evolves rapidly because of a high mutation rate and may escape acquired immunity [4].

\footnotetext{
*Correspondence: kvandersluijs@amc.uva.nl

'Departments of Pulmonology and Experimental Immunology, Academic Medical Center, PO Box 22700, 1100 DE, Amsterdam, The Netherlands

Full list of author information is available at the end of the article
}

This antigenic drift is the major reason why outbreaks of influenza occur every winter. In addition, the segmented genome of influenza virus also increases the risk of recombination of two or more influenza strains [4]. These major changes in the viral genome, also referred to as antigenic shift, could lead to a pandemic outbreak of influenza [5]. Although influenza virus itself can lead to severe pneumonia, mortality is most often caused by complications of the infection or by pre-existing conditions, such as asthma, chronic obstructive pulmonary disease, pulmonary fibrosis or cardiovascular disease [6-9]. Viruses are well known to cause exacerbations of asthma and chronic obstructive pulmonary disease, but the association between influenza virus and cardiovascular disease is less clear. Nevertheless, epidemiological studies indicate that the incidence of myocardial infarction and stroke correlates with the incidence of influenza [10], while influenza vaccination has been shown to reduce the risk of these cardiovascular events. Whether these epidemiological findings correlate with the pro-thrombotic state observed during influenza virus infection is still unclear [11].

\section{Epidemiology of secondary bacterial pneumonia}

Bacterial superinfection is a common cause of influenzarelated hospitalization of otherwise healthy individuals [12]. Primary influenza virus infection may lead to lower respiratory tract symptoms, but secondary bacterial infections during and shortly after recovery from influenza virus infection are a much more common cause of pneumonia. Although pandemic strains are usually more pathogenic than seasonal influenza strains, the excess mortality rates during pandemics is mainly caused by secondary bacterial pneumonia [13]. Retrospective analysis of post-mortem lung tissue of individuals that died from the 1918 pandemic influenza strain indicated that most of these people also had a bacterial infection. Also, during the influenza pandemic of 1957 more than two-thirds of fatal cases were associated with bacterial pneumonia [14]. Bacteria such as Staphylococcus aureus and Haemophilus influenzae are known to cause 
Combined viral/bacterial pneumonia

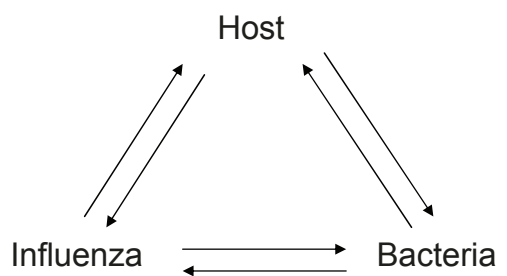

Post-influenza pneumonia

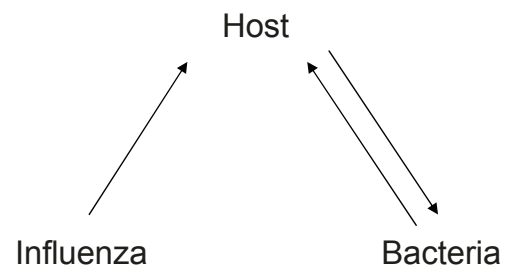

Figure 1. Complexity of combined viral/bacterial and post-influenza pneumonia. Severe bacterial pneumonia following influenza can be subdivided into combined viral/bacterial (left) and post-influenza pneumonia (right). During combined viral/bacterial pneumonia, the virus, the bacteria and the host all interact with each other. The severity of post-influenza pneumonia is due to virus-induced changes to the host that affect the course of bacterial infection.

post-influenza pneumonia, but Streptococcus pneumoniae is the most prominent pathogen involved [15]. A recent report on the new $\mathrm{H} 1 \mathrm{~N} 1$ influenza strain indicates that $29 \%$ of fatal H1N1 cases between May 2009 and August 2009 in the United States were associated with a secondary bacterial infection [16], which is markedly less than for previous influenza pandemics [17,18]. In addition to $S$. aureus and S. pneumoniae, Streptococcus pyogenes was also frequently isolated [16,18]. Primary infections with these pathogens are usually less severe than secondary infections. The incidence of invasive pneumococcal disease closely correlates with the influenza season [19], and pneumococcal vaccination not only results in an overall reduced number of pneumonia cases, it also leads to markedly reduced cases of virusassociated pneumonia [20]. Although secondary bacterial pneumonia has been described for other respiratory viruses as well, the morbidity and mortality is much lower than observed for influenza [21,22].

\section{Pathogenesis of bacterial pneumonia with influenza}

Bacterial respiratory infection during influenza virus infection can be divided into combined viral/bacterial pneumonia or secondary bacterial infection following influenza. Clinical symptoms do not distinguish between bacterial and viral pneumonia early in the course of disease, rendering early clinical distinction a challenge. Critically ill patients with viral pneumonia present with bilateral interstitial infiltrates on the chest radiograph indistinguishable from bacterial pneumonia [23]. Other markers of inflammation are also not specific. Distinction between viral and bacterial pneumonia by microbiological and/or molecular techniques, however, is highly relevant in terms of initiating antimicrobial therapy, as $32 \%$ of patients with viral pneumonia develop a concomitant bacterial pneumonia [23]. Secondary bacterial infections following influenza are more easily recognized clinically compared to combined viral/bacterial pneumonia, since these bacterial infections tend to occur during the recovery phase from influenza [24]. Epidemiological studies indicate that individuals infected with influenza virus are most susceptible to secondary bacterial pneumonia between 4 and 14 days after the onset of influenza symptoms [25].

Although the incidence of a secondary bacterial infection does not show a clear distinction between combined viral/bacterial pneumonia and secondary bacterial infection following influenza, the processes leading to severe bacterial pneumonia in conjunction with influenza virus infections are multifactorial and differ between early and late bacterial infection. During combined viral/ bacterial infection, the virus not only interacts with the host response, it also interacts with bacterial-induced inflammation, increasing bacterial colonization and outgrowth as well as viral replication (Figure 1). Conversely, the host response to both pathogens will affect viral replication and bacterial growth [26,27]. From a mechanistic point of view, post-influenza pneumonia is less complicated than combined viral/bacterial pneumonia, since the virus has been cleared (Figure 1). The pathogenesis of post-influenza pneumonia involves virus-induced changes to the host $[28,29]$. These differences are important to take into consideration when studying the mechanisms of secondary bacterial complications and may also have an impact on therapeutic strategies to be followed when patients are hospitalized for influenza complicated by pneumonia.

The severity of combined viral/bacterial infection or post-influenza pneumococcal pneumonia is classically attributed to influenza-induced damage to the airway epithelium, which leads to increased colonization of bacteria at the basal membrane [30]. Influenza virus preferentially infects and replicates in airway epithelial cells, leading to the induction of an antiviral process in order to eradicate the virus. Besides limiting viral replication by means of transcriptional and translational 
Table 1. Predisposing factors identified for combined viral/bacterial pneumonia and/or post-influenza pneumonia

\begin{tabular}{|c|c|c|}
\hline & $\begin{array}{l}\text { Factors associated with combined } \\
\text { viral/bacterial infection }\end{array}$ & $\begin{array}{l}\text { Factors associated with } \\
\text { post-influenza pneumonia }\end{array}$ \\
\hline Viral factors & $\begin{array}{l}\text { Viral neuraminidase }[37,38] \\
\text { PB1-F2 [39] }\end{array}$ & Not involved, that is, virus is cleared $[28,29]$ \\
\hline Bacterial factors & Pneumococcal surface protein A [40] & Unknown \\
\hline Mechanical factors (host) & $\begin{array}{l}\text { Epithelial injury [30] } \\
\text { Mucociliary velocity [33] }\end{array}$ & Unknown \\
\hline Immune cells (host) & $\begin{array}{l}\text { Neutrophil function }[34,47,49,51,57] \\
\text { Neutrophil recruitment }[52,53,55] \\
\text { Neutrophil apoptosis }[48,54] \\
\text { Macrophages }[57,58] \\
\text { Monocytes }[57]\end{array}$ & $\begin{array}{l}\text { Neutrophil function [28] } \\
\text { Neutrophil recruitment [29] }\end{array}$ \\
\hline Cytokines/chemokines (host) & $\begin{array}{l}\text { IFN- } \gamma[59] \\
\text { IFN- } / / \beta[53] \\
\text { KC }[53] \\
\text { MIP-2 [53] }\end{array}$ & IL-10 [28] \\
\hline Pattern recognition receptors (host) & MARCO [59] & $\begin{array}{l}\text { TLR2 [29] } \\
\text { TLR4 [29] } \\
\text { TLR5 [29] }\end{array}$ \\
\hline Metabolic enzymes (host) & Unknown & Indoleamine 2,3-dioxygenase [61] \\
\hline
\end{tabular}

Abbreviations: IFN, interferon; IL, interleukin; KC, keratinocyte-derived chemokine; MARCO, macrophage receptor with collagenous structure; MIP, macrophage inflammatory protein; TLR, Toll-like receptor

inhibition, epithelial cells are instructed to undergo apoptosis [31]. The apoptotic bodies containing the virus are subsequently removed by (alveolar) macrophages [32]. Major drawbacks of this antiviral mechanism include not only the increased risk of bacterial colonization, but also enhanced invasion by bacteria. In addition to epithelial injury, mucociliary clearance has recently been shown to be impaired during influenza virus infection, leading to an enhanced burden of S. pneumoniae already at 2 hours after bacterial challenge [33].

Over the past few years it has become increasingly clear that epithelial injury is not the only factor that contributes to the severe outcome resulting from bacterial complications during influenza infection [27-29,33, 34]. Mouse studies have revealed additional mechanisms that play a critical role in either combined viral/bacterial infection or post-influenza pneumococcal pneumonia (summarized in Table 1). Most mouse models that are currently used focus on combined viral/bacterial pneumonia (bacterial challenges up to 7 days after influenza) [25,33-35], while other models are used to investigate post-influenza pneumonia [28,29] (bacterial challenges ranging from 14 days up to 35 days after influenza infection).

\section{Viral factors contributing to secondary bacterial complications}

Several viral factors have been identified as critical for the development of secondary bacterial pneumonia. Viral neuraminidase has been shown to enhance bacterial growth as well as bacterial dissemination in a mouse model for secondary pneumococcal pneumonia. Studies with recombinant influenza strains containing different neuraminidase genes indicate that neuraminidase activity correlates with increased adhesion of pneumococci to airway epithelial cells, which could be reversed by adding neuraminidase inhibitors [36]. Influenza strains with relatively high neuraminidase activity, such as the 1957 pandemic influenza strain, were associated with an increased incidence of pneumococcal pneumonia and higher mortality rates in mice after bacterial challenge [37]. In addition, mice treated with neuraminidase inhibitors for up to 5 days after viral exposure showed markedly increased survival rates. Nevertheless, neuraminidase inhibitors were only partially protective in this model for bacterial complications following influenza virus infection [38].

In addition to neuraminidase, PB1-F2, a pro-apoptotic protein expressed by most influenza A strains, has been implicated in the pathogenesis of secondary bacterial pneumonia as well. Mice infected with viral strains lacking PB1-F2 were largely protected against secondary bacterial complications. In line with this, mice infected with a viral strain that expresses the PB1-F2 protein from the 1918 pandemic influenza strain appeared to be highly susceptible to pneumococcal pneumonia [39]. Since PB1-F2 did not have an impact on bacterial loads and since it has been implicated in the pathogenesis of primary infection with influenza virus, it may be concluded that PB1-F2 induces lung pathology during viral infection, which may enhance the inflammatory response to a secondary challenge. The underlying mechanism of PB1-F2-induced lung pathology is largely unknown. 


\section{Bacterial factors contributing to secondary bacterial pneumonia}

Bacterial components that contribute to secondary bacterial pneumonia have been poorly investigated. In contrast to viral neuraminidase, bacterial neuraminidase has not been implicated in combined viral/bacterial pneumonia or post-influenza pneumonia $[34,37,40]$. The fact that bacterial neuraminidase does not contribute to enhanced replication of influenza is most likely due to poor enzymatic activity compared to viral neuraminidase and the strict sialic acid substrate requirements of bacterial neuraminidase.

In contrast, pneumococcal surface protein A (PspA) has been shown to increase bacterial colonization in mice infected with influenza virus [40]. PspA is known to interfere with complement-mediated phagocytosis and lactoferrin-mediated killing. However, it is also identified as a virulence factor for primary pneumococcal pneumonia [41]. As such, PspA seems to have a limited contribution to the severe outcome of bacterial pneumonia with influenza. Similarly, pneumococcal hyaluronidase has been identified as a virulence factor for primary pneumococcal pneumonia, but did not have an impact on pneumococcal pneumonia following influenza [40].

S. pneumoniae has been shown to bind to the plateletactivating factor receptor (PAFR) through phosphatidylcholine in the bacterial cell wall [42], which has been suggested to increase colonization of bacteria and/or to mediate transition from the lung to the blood [43]. The impact of this interaction was further investigated using PAFR knockout mice $[44,45]$ and pharmacological inhibitors of PAFR [35]. Although influenza virus has been shown to upregulate the expression of PAFR [43], no studies have identified a more pronounced role for it in secondary pneumococcal pneumonia compared to primary pneumococcal infection [35,44,45]. PAFR appears to mediate invasive pneumococcal disease during primary and secondary pneumococcal pneumonia, while colonization within the lung seems to be dependent on the bacterial strain [43-45].

In conclusion, there is little evidence that bacterial virulence plays an important role in the pathogenesis of secondary pneumococcal pneumonia after influenza. Protease activity by $S$. aureus has been shown to increase the virulence of influenza A virus in mice by cleaving virus hemagglutinin. However, protease inhibitors have not been further investigated in models of secondary bacterial pneumonia [46].

\section{Host factors contributing to secondary bacterial pneumonia}

Most studies on the mechanism underlying bacterial pneumonia following influenza have focused on impaired host defense against secondary infection with an unrelated pathogen. Influenza virus infection has been shown to impair neutrophil function at multiple levels [28,34,4754]. Initial studies indicated that influenza virus reduces chemotaxis and chemokinesis of neutrophils in vitro and in vivo [55], which appeared to be strain-dependent in subsequent studies with patients infected with influenza virus [52]. In addition to this direct inhibitory mechanism, a recent study identified type I interferon (IFN), an antiviral cytokine, as an important factor in the downregulation of relevant chemokines, such as keratinocyte-derived chemokine and macrophage inflammatory protein 2 , thereby inhibiting the migration of neutrophils [53]. However, several studies reported increased, rather than reduced, numbers of neutrophils after secondary bacterial challenge in mice infected with influenza virus $[28,34,56]$. The increased number of neutrophils may correlate with higher bacterial loads in these models of secondary bacterial pneumonia. The higher bacterial loads might be explained by a reduced phagocytic capacity of neutrophils $[28,34,45,57,58]$. In vitro studies with ultraviolet irradiated and heat killed influenza virus indicated that the reduction in phagocytic capacity is mediated, at least in part, by viral neuraminidase activity [58]. Nevertheless, the impaired effector function is still present after the virus has been cleared [28], indicating that host factors contribute to impaired bacterial killing. IL-10 production is synergistically enhanced in mice infected with S. pneumoniae during viral infection $[38,56]$ as well as after clearance [28] of influenza virus. Inhibition of IL-10 markedly improved survival in a mouse-model for post-influenza pneumococcal pneumonia, which was associated with reduced bacterial loads. The role of IL-10 in combined viral/ bacterial pneumonia seems to be limited, since IL-10 knockout mice did not show an improved response to secondary bacterial infection [59]. It should be noted, however, that IL-10 knockout mice respond differently to primary viral infection as well, leading to a more pronounced proinflammatory state [60]. Together, these findings not only illustrate the complexity of secondary bacterial pneumonia, they also stress that combined viral/bacterial infection is intrinsically different from post-influenza pneumonia.

The tryptophan-catabolizing enzyme indoleamine 2,3-dioxygenase (IDO) has been shown to enhance IL-10 levels in a mouse model for post-influenza pneumococcal pneumonia [61]. Inhibition of IDO, which is expressed during the recovery phase of influenza infection, reduced bacterial loads during secondary, but not primary, pneumococcal infection. Despite a clear reduction in bacterial loads as well as markedly reduced levels of IL-10 and TNF- $\alpha$, it did not have an impact on survival. It is unlikely, therefore, that IDO predisposes for bacterial pneumonia by means of enhancing IL-10 production. 
Recent observations in our laboratory indicate that local IDO activity induces apoptosis of neutrophils during bacterial infection of the airways (submitted for publication). IDO-mediated apoptosis, which has been extensively studied for $\mathrm{T}$ lymphocytes, is particularly mediated by metabolites such as kynurenine and 3-hydroxy anthranilic acid, rather than depletion of tryptophan. Tryptophan metabolites have been implicated in monocyte and macrophage apoptosis as well [62,63]. Together, these data indicate that IDO functions as a natural mechanism to remove inflammatory cells. This mechanism to resolve inflammation prevents excessive damage to the airways after viral infection, but increases the susceptibility to secondary bacterial pneumonia.

In addition to neutrophils, macrophages and monocytes $[58,64]$ have also been shown to have a reduced phagocytic capacity during influenza infection. IFN- $\gamma$ has been shown to play a critical role in macrophage dysfunction through downregulation of 'macrophage receptor with collagenous structure' (MARCO) expression on alveolar macrophages [65]. MARCO can be classified as a scavenger receptor involved in the innate recognition and subsequent killing of bacteria. MARCO knockout mice have been shown to be more susceptible to pneumococcal pneumonia, which was associated with higher bacterial loads, enhanced lung pathology and increased mortality rates [63]. Although other factors that mediate opsonization or phagocytosis of bacteria have been extensively studied for primary bacterial pneumonia [66-68], their roles in either combined viral/ bacterial pneumonia or post-influenza pneumonia are largely unknown.

Knowledge about the role of other pattern recognition receptors, such as Toll-like receptors (TLRs), is limited. A recent study indicated that influenza virus infection resulted in sustained desensitization of TLRs for up to 6 weeks after influenza virus infection [29]. Mice exposed to influenza virus exert a poor response to lipopolysaccharide, lipoteichoic acid and flagellin, ligands for TLR4, TLR2 and TLR5, respectively, as reflected by reduced neutrophil numbers in bronchoalveolar lavage fluid. These data are supported by the fact that TLR2 knockout mice were equally susceptible to secondary bacterial pneumonia following influenza virus infection compared to wild-type mice [69]. It is worth noting that TLR4 can compensate for a defect in TLR2 during primary pneumococcal pneumonia [70]. In addition to TLR desensitization, CD200R expression has been proposed to impair the host response towards bacteria during influenza virus infection [71]. Although CD200CD200R interactions have been shown to negatively regulate inflammation through induction of IDO [72], its role in secondary bacterial pneumonia has not been investigated yet.
Taken together, these host factors contributing to severe post-influenza pneumonia all relate to altered innate immune mechanisms that are supposed to resolve or dampen virus-induced inflammation and related tissue damage. It should be noted that most studies have been performed using mouse models for combined viral/ bacterial pneumonia or post-influenza bacterial pneumonia and require confirmation in humans.

\section{Current treatment options}

Vaccination against influenza has been shown to reduce mortality rates during influenza epidemics [73]. Seasonal influenza epidemics are primarily caused by antigenic drift (that is, single-point mutations that are caused by the high mutation rate of influenza virus strains). Although single-point mutations occur at random, genetic changes can be predicted in advance [74]. These predictions provide the opportunity to develop vaccines to prevent seasonal influenza and therefore also the risk of secondary bacterial infections. Vaccination of elderly patients has been shown to reduce hospitalizations by $52 \%$. In contrast to seasonal influenza, pandemic influenza, such as caused by the recently emerged H1N1 strain $[3,75]$, results from antigenic shift. It is hard to predict when these changes occur and which strains are involved. It is virtually impossible, therefore, to develop vaccines directed against pandemic influenza strains in advance. Vaccines against new influenza strains only become available when the vaccine has been validated extensively.

Besides vaccination, treatment options to prevent a complicated course of influenza is to inhibit viral replication with antiviral agents, such as amantadine $\left(\right.$ Symmetrel $\left.^{\circ}\right)$, or neuraminidase inhibitors, such as oseltamivir (Tamiflu ${ }^{\odot}$ ) and zanamivir (Relenza $\left.{ }^{\circ}\right)$. These agents have been shown to reduce influenza-related symptoms [76-78], but their efficacy against bacterial complications remains to be determined [79]. Viral neuraminidase has been shown to be involved in the enhanced response to bacteria in a mouse model for post-influenza pneumococcal pneumonia [37]. Moreover, mice treated with neuraminidase inhibitors were less susceptible to secondary bacterial infections. However, neuraminidase inhibitors did not completely prevent mortality in mice with influenza complicated by bacterial pneumonia, which may relate to the relatively small timewindow in which neuraminidase inhibitors can reduce viral replication [80]. In addition, the efficacy of neuraminidase inhibitors in established viral/bacterial pneumonia was not tested. Rimantadine, an amantadine analogue, did not improve mortality in mice with postinfluenza pneumococcal pneumonia [33]. The efficacy of these inhibitors in the treatment of bacterial complications in humans has not been established yet. These 
approaches mainly focus on the prevention of secondary bacterial pneumonia.

Patients with community-acquired pneumonia who demonstrate or have demonstrated signs and symptoms of illness compatible with influenza in the days or weeks before should be empirically treated with antibiotics targeting S. pneumoniae and S. aureus in order to cover the most common pathogens causing the most severe secondary infections, and coverage of $H$. influenzae is also recommended [81]. Appropriate antimicrobial agents therefore include cefotaxime, ceftriaxone and respiratory fluoroquinolones. As mentioned above, combined infection needs to be confirmed by microbiological and molecular techniques. When samples from respiratory tract are proven culture negative, antibiotics can be stopped. Treatment targeted at methicillinresistant S. aureus (by vancomycin or linezolid) should be limited to patients with confirmed infection or a compatible clinical presentation (shock and necrotizing pneumonia) [80]. Of note, mouse studies indicate that ampicillin treatment is insufficient to prevent mortality in a model for secondary bacterial pneumonia, while the bacteriostatic protein synthesis inhibitors clindamycin or azithromycin improve the outcome after streptococcal pneumonia in influenza-infected mice [82]. This protective effect is likely mediated by inhibition of toxin release [82], but it may be associated with the antiinflammatory properties of these latter antimicrobial agents as well $[83,84]$. Although ampicillin alone did not have an impact on survival in influenza-infected mice with secondary pneumococcal pneumonia, it did improve mortality rates in mice previously treated with oseltamivir compared to mice treated with oseltamivir alone [37].

\section{Future perspectives}

Secondary bacterial complications are the result of an altered host response due to influenza virus infection. Most factors that have been identified to play a critical role in post-influenza pneumococcal pneumonia are in fact mechanisms to prevent excessive inflammation and/ or to promote resolution of inflammation, which are initiated to restore tissue homeostasis after clearance of the primary infection. At the same time, these mechanisms greatly impair the host response towards secondary unrelated pathogens. Cytokines and chemokines appear to play a critical role in dampening virus-induced immunopathology. IFN- $\gamma$ and IL-10 have been shown to alter macrophage and neutrophil function, respectively, while type I IFN seems to impair neutrophil recruitment after secondary bacterial infection. In addition, IDO expression is induced by proinflammatory cytokines such as TNF- $\alpha$, IFN- $\gamma$, IL-12 and IL-18, leading to apoptosis of inflammatory cells. Although the contribution of these
This article is part of a review series on Influenza, edited by Steven Opal. Other articles in the series can be found online at http:// ccforum.com/series/influenza

mediators needs to be confirmed in humans, targeting cytokines may be an alternative approach to trigger an effective host response to bacteria. Although it is practically not feasible to neutralize these inflammatory mediators as prophylactic treatment to prevent secondary bacterial pneumonia in all influenza-infected subjects, it may be a useful approach in hospitalized subjects, especially those that are admitted to the intensive care unit.

\section{Conclusion}

Influenza may be complicated by bacterial pneumonia. It is important to consider the time interval between viral and bacterial infection. At present, antibiotic treatment appears to be the only therapeutic option for postinfluenza pneumonia. Further insight into the underlying mechanisms in combined viral/bacterial infection and post-influenza pneumonia may provide new targets for the treatment of these complicated infections.

\section{Abbreviations}

IDO = indoleamine 2,3-dioxygenase; IFN = interferon; IL = interleukin; $\mathrm{MARCO}=$ macrophage receptor with collagenous structure; PAFR = plateletactivating factor receptor; $\mathrm{PspA}=$ pneumococcal surface protein $\mathrm{A} ; \mathrm{TLR}=$ Toll-like receptor; TNF = tumor necrosis factor.

Competing interests

The authors declare that they have no competing interests.

\section{Author details}

'Departments of Pulmonology and Experimental Immunology, Academic Medical Center, PO Box 22700, 1100 DE, Amsterdam, The Netherlands. ${ }^{2}$ Center for Experimental and Molecular Medicine, Academic Medical Center, PO Box 22700, 1100 DE, Amsterdam, The Netherlands. ${ }^{3}$ Department of Intensive Care Medicine and Laboratory of Experimental Intensive Care and Anesthesiology, Academic Medical Center, PO Box 22700, 1100 DE, Amsterdam, The Netherlands.

Published: 19 April 2010

\section{References}

1. Monto AS: Epidemiology of influenza. Epidemiology of influenza. Vaccine 2008, 26:D45-48

2. Eccles R: Understanding the symptoms of the common cold and influenza. Lancet Infect Dis 2005, 5:718-725.

3. Novel Swine-Origin Influenza A (H1N1) Virus Investigation Team, Dawood FS, Jain S, Finelli L, Shaw MW, Lindstrom S, Garten RJ, Gubareva LV, Xu X, Bridges $C B$, Uyeki TM: Emergence of a novel swine-origin influenza $A(H 1 N 1)$ virus in humans. N Engl J Med 2009, 360:2605-2615.

4. Scholtissek C: Molecular evolution of influenza viruses. Virus Genes 1995, 11:209-215.

5. Hilleman MR: Realities and enigmas of human viral influenza: pathogenesis, epidemiology and control. Vaccine 2002, 20:3068-3087.

6. Glezen WP: Asthma, influenza, and vaccination. J Allergy Clin Immunol 2006, 118:1199-1206.

7. Mallia P, Johnston SL: Influenza infection and COPD. Int J Chron Obstruct Pulmon Dis 2007, 2:55-64.

8. Rajan S, Saiman L: Pulmonary infections in patients with cystic fibrosis. Semin Respir Infect 2002, 17:47-56. 
9. Mamas MA, Fraser D, Neyses L: Cardiovascular manifestations associated with influenza virus infection. Int J Cardiol 2008, 130:304-309.

10. Smeeth L, Thomas SL, Hall AJ, Hubbard R, Farrington P, Vallance P: Risk of myocardial infarction and stroke after acute infection or vaccination. N Engl J Med 2004, 351:2611-2618.

11. Keller TT, van der Sluijs KF, de Kruif MD, Gerdes VE, Meijers JC, Florquin S, van der Poll T, van Gorp EC, Brandjes DP, Büller HR, Levi M: Effects on coagulation and fibrinolysis induced by influenza in mice with a reduced capacity to generate activated protein $\mathrm{C}$ and a deficiency in plasminogen activator inhibitor type 1. Circ Res 2006, 99:1261-1269.

12. Morens DM, Taubenberger JK, Fauci AS: Predominant role of bacterial pneumonia as a cause of death in pandemic influenza: implications for pandemic influenza preparedness. J Infect Dis 2008, 198:962-970.

13. Hers JF, Masurel N, Mulder J: Bacteriology and histopathology of the respiratory tract and lungs in fatal Asian influenza. Lancet 1958, 2:1141-1143.

14. de Roux A, Ewig S, García E, Marcos MA, Mensa J, Lode H, Torres A: Mixed community-acquired pneumonia in hospitalised patients. Eur Respir $\int 2006$ 27:795-800

15. Grabowska K, Högberg L, Penttinen P, Svensson A, Ekdahl K: Occurrence of invasive pneumococcal disease and number of excess cases due to influenza. BMC Infect Dis 2006, 6:58.

16. Centers for Disease Control and Prevention (CDC): Bacterial coinfections in lung tissue specimens from fatal cases of 2009 pandemic influenza A (H1N1) - United States, May-August 2009. MMWR Morb Mortal Wkly Rep 2009, 58:1071-1074

17. Louie JK, Acosta M, Winter K, Jean C, Gavali S, Schechter R, Vugia D, Harriman K, Matyas B, Glaser CA, Samuel MC, Rosenberg J, Talarico J, Hatch D; California Pandemic (H1N1) Working Group: Factors associated with death or hospitalization due to pandemic 2009 influenza $A(H 1 N 1)$ infection in California. JAMA 2009, 302:1896-1902.

18. Rothberg MB, Haessler SD: Complications of seasonal and pandemic influenza. Crit Care Med, in press.

19. Khater F, Moorman JP: Complications of influenza. South Med J 2003, 96:740-743

20. Oliveira EC, Marik PE, Colice G: Influenza pneumonia: a descriptive study. Chest 2001, 119:1717-1723.

21. Talbot TR, Poehling KA, Hartert TV, Arbogast PG, Halasa NB, Edwards KM, Schaffner W, Craig AS, Griffin MR: Seasonality of invasive pneumococcal disease: temporal relation to documented influenza and respiratory syncytial viral circulation. Am J Med 2005, 118:285-291.

22. Patel J, Faden H, Sharma S, Ogra PL: Effect of respiratory syncytial virus on adherence, colonization and immunity of non-typable Haemophilus influenzae: implications for otitis media. Int J Pediatr Otorhinolaryngol 1992 23:15-23.

23. Kumar A, Zarychanski R, Pinto R, Cook DJ, Marshall J, Lacroix J, Stelfox T, Bagshaw S, Choong K, Lamontagne F, Turgeon AF, Lapinsky S, Ahern SP, Smith O, Siddiqui F, Jouvet P, Khwaja K, McIntyre L, Menon K, Hutchison J, Hornstein D, Joffe A, Lauzier F, Singh J, Karachi T, Wiebe K, Olafson K, Ramsey C, Sharma S, Dodek P, Meade M, Hall R, Fowler RA; Canadian Critical Care Trials Group H1N1 Collaborative: Critically ill patients with 2009 influenza A(H1N1) infection in Canada. JAMA 2009, 302:1872-1879.

24. Madhi SA, Klugman KP; Vaccine Trialist Group: A role for Streptococcus pneumoniae in virus-associated pneumonia. Nat Med 2004, 10:811-813.

25. Boyd M, Clezy K, Lindley R, Pearce R: Pandemic influenza: clinical issues. Med J Aust 2006, 185:S44-S47.

26. Jakab, GJ: Mechanisms of bacterial superinfections in viral pneumonias. Schweiz Med Wschr 1985, 115:75-86.

27. Jones WT, Menna JH, Wennerstrom DE: Lethal synergism induced in mice by influenza type A virus and type la group B streptococci. Infect Immun 1983, 41:618-623.

28. van der Sluiis KF, van Elden LJ, Nijhuis M, Schuurman R, Pater JM, Florquin S, Goldman M, Jansen HM, Lutter R, van der Poll T: IL-10 is an important mediator of the enhanced susceptibility to pneumococcal pneumonia after influenza infection. J Immuno/ 2004, 172:7603-7609.

29. Didierlaurent A, Goulding J, Patel S, Snelgrove R, Low L, Bebien M, Lawrence T, van Rijt LS, Lambrecht BN, Sirard JC, Hussell T: Sustained desensitization to bacterial Toll-like receptor ligands after resolution of respiratory influenza infection. J Exp Med 2008, 205:323-329.

30. Plotkowski MC, Puchelle E, Beck G, Jacquot J, Hannoun C: Adherence of type I Streptococcus pneumoniae to tracheal epithelium of mice infected with influenza A/PR8 virus. Am Rev Respir Dis 1986, 134:1040-1044.

31. Brydon EW, Smith H, Sweet C: Influenza A virus-induced apoptosis in bronchiolar epithelial ( $\mathrm{NCl}-\mathrm{H} 292)$ cells limits pro-inflammatory cytokine release. J Gen Virol 2003, 84:2389-2400.

32. Fujimoto I, Pan J, Takizawa T, Nakanishi Y: Virus clearance through apoptosisdependent phagocytosis of influenza A virus-infected cells by macrophages. J Virol 2000, 74:3399-3403.

33. Pittet LA, Hall-Stoodley L, Rutkowski MR, Harmsen AG: Influenza virus infection decreases tracheal mucociliary velocity and clearance of Streptococcus pneumoniae. Am J Respir Cell Mol Biol, in press.

34. LeVine AM, Koeningsknecht V, Stark JM: Decreased pulmonary clearance of S. pneumoniae following influenza A infection in mice. J Virol Methods 2001, 94:173-186

35. McCullers JA, Rehg JE: Lethal synergism between influenza virus and Streptococcus pneumoniae: characterization of a mouse model and the role of platelet-activating factor receptor. I Infect Dis 2002, 186:341-350.

36. MCCullers JA, Bartmess KC: Role of neuraminidase in lethal synergism between influenza virus and Streptococcus pneumoniae. J Infect Dis 2003, 187:1000-1009.

37. Peltola VT, Murti KG, McCullers JA: Influenza virus neuraminidase contributes to secondary bacterial pneumonia. J Infect Dis 2005, 192:249-257.

38. McCullers JA: Effect of antiviral treatment on the outcome of secondary bacterial pneumonia after influenza. J Infect Dis 2004, 190:519-526.

39. McAuley JL, Hornung F, Boyd KL, Smith AM, McKeon R, Bennink J, Yewdell JW McCullers JA: Expression of the 1918 influenza A virus PB1-F2 enhances the pathogenesis of viral and secondary bacterial pneumonia. Cell Host Microbe 2007, 2:240-249.

40. King QO, Lei B, Harmsen AG: Pneumococcal surface protein A contributes to secondary Streptococcus pneumoniae infection after influenza virus infection. J Infect Dis 2009, 200:537-545.

41. Berry AM, Paton JC: Additive attenuation of virulence of Streptococcus pneumoniae by mutation of the genes encoding pneumolysin and other putative pneumococcal virulence proteins. Infect Immun 2000, 68:133-140.

42. Cundell DR, Gerard NP, Gerard C, Idanpaan-Heikkila I, Tuomanen El: Streptococcus pneumoniae anchor to activated human cells by the receptor for platelet-activating factor. Nature 1995, 377:435-438.

43. McCullers JA, Iverson AR, McKeon R, Murray PJ: The platelet activating factor receptor is not required for exacerbation of bacterial pneumonia following influenza. Scand J Infect Dis 2008, 40:11-17

44. van der Sluijs KF, van Elden LJ, Nijhuis M, Schuurman R, Florquin S, Shimizu T, Ishii S, Jansen HM, Lutter R, van der Poll T: Involvement of the plateletactivating factor receptor in host defense against Streptococcus pneumoniae during postinfluenza pneumonia. Am J Physiol Lung Cell Mol Physiol 2006, 290:L194-L199.

45. Rijneveld AW, Weijer S, Florquin S, Speelman P, Shimizu T, Ishii S, van der Poll T: Improved host defense against pneumococcal pneumonia in plateletactivating factor receptor-deficient mice. J Infect Dis 2004, 189:711-716.

46. Tashiro M, Klenk HD, Rott R: Inhibitory effect of a protease inhibitor, leupeptin, on the development of influenza pneumonia, mediated by concomitant bacteria. J Gen Virol 1987, 68:2039-2041

47. McNamee LA, Harmsen AG: Both influenza-induced neutrophil dysfunction and neutrophil-independent mechanisms contribute to increased susceptibility to a secondary Streptococcus pneumoniae infection. Infect Immun 2006, 74:6707-6721.

48. Engelich $G$, White M, Hartshorn KL: Neutrophil survival is markedly reduced by incubation with influenza virus and Streptococcus pneumoniae: role of respiratory burst. J Leukoc Biol 2001, 69:50-56.

49. Abramson JS, Hudnor HR: Effect of priming polymorphonuclear leukocytes with cytokines (granulocyte-macrophage colony-stimulating factor [GM-CSF] and G-CSF) on the host resistance to Streptococcus pneumoniae in chinchillas infected with influenza A virus. Blood 1994, 83:1929-1934.

50. Cassidy LF, Lyles DS, Abramson JS: Depression of polymorphonuclear leukocyte functions by purified influenza virus hemagglutinin and sialic acid-binding lectins. J Immuno/ 1989, 142:4401-4406.

51. Verhoef J, Mills EL, Debets-Ossenkopp Y, Verbrugh HA: The effect of influenza virus on oxygen-dependent metabolism of human neutrophils. Adv Exp Med Biol 1982, 141:647-654

52. Larson HE, Parry RP, Tyrrell DA: Impaired polymorphonuclear leucocyte chemotaxis after influenza virus infection. Br J Dis Chest 1980, 74:56-62.

53. Shahangian A, Chow EK, Tian X, Kang JR, Ghaffari A, Liu SY, Belperio JA, Cheng 
G, Deng JC: Type I IFNs mediate development of postinfluenza bacterial pneumonia in mice. J Clin Invest 2009, 119:1910-1920.

54. Colamussi ML, White MR, Crouch E, Hartshorn KL: Influenza A virus accelerates neutrophil apoptosis and markedly potentiates apoptotic effects of bacteria. Blood 1999, 93:2395-2403.

55. Ruutu P, Vaheri A, Kosunen TU: Depression of human neutrophil motility by influenza virus in vitro. Scand J Immunol 1977, 6:897-906.

56. Smith MW, Schmidt JE, Rehg JE, Orihuela CJ, McCullers JA: Induction of pro- and anti-inflammatory molecules in a mouse model of pneumococcal pneumonia after influenza. Comp Med 2007, 57:82-89.

57. Abramson JS, Mills EL, Giebink GS, Quie PG: Depression of monocyte and polymorphonuclear leukocyte oxidative metabolism and bactericidal capacity by influenza A virus. Infect Immun 1982, 35:350-355.

58. Debets-Ossenkopp Y, Mills EL, van Dijk WC, Verbrugh HA, Verhoef J: Effect of influenza virus on phagocytic cells. Eur J Clin Microbiol 1982, 1:171-177.

59. Sun K, Metzger DW: Inhibition of pulmonary antibacterial defense by interferon-gamma during recovery from influenza infection. Nat Med 2008 , 14:558-564.

60. Sun J, Madan R, Karp CL, Braciale TJ: Effector T cells control lung inflammation during acute influenza virus infection by producing IL-10. Nat Med 2009, 15:277-284.

61. van der Sluiis KF, Nijhuis M, Levels JH, Florquin S, Mellor AL, Jansen HM, van der Poll T, Lutter R: Influenza-induced expression of indoleamine 2,3-dioxygenase enhances interleukin-10 production and bacterial outgrowth during secondary pneumococcal pneumonia. J Infect Dis 2006, 193:214-222.

62. Morita T, Saito K, Takemura M, Maekawa N, Fujigaki S, Fujii H, Wada H, Takeuchi S, Noma A, Seishima M: 3-Hydroxyanthranilic acid, an Ltryptophan metabolite, induces apoptosis in monocyte-derived cells stimulated by interferon-gamma. Ann Clin Biochem 2001, 38:242-251.

63. Fallarino F, Grohmann U, Vacca C, Bianchi R, Orabona C, Spreca A, Fioretti MC, Puccetti P: T cell apoptosis by tryptophan catabolism. Cell Death Differ 2002, 9:1069-1077.

64. Astry $\mathrm{CL}$, Jakab GJ: Influenza virus-induced immune complexes suppress alveolar macrophage phagocytosis. J Virol 1984, 50:287-292.

65. Arredouani M, Yang Z, Ning Y, Qin G, Soininen R, Tryggvason K, Kobzik L: The scavenger receptor MARCO is required for lung defense against pneumococcal pneumonia and inhaled particles. J Exp Med 2004 200:267-272.

66. Gordon SB, Irving GR, Lawson RA, Lee ME, Read RC: Intracellular trafficking and killing of Streptococcus pneumoniae by human alveolar macrophages are influenced by opsonins. Infect Immun 2000, 68:2286-2293.

67. Ali F, Lee ME, lannelli F, Pozzi G, Mitchell TJ, Read RC, Dockrell DH: Streptococcus pneumoniae-associated human macrophage apoptosis after bacterial internalization via complement and Fcgamma receptors correlates with intracellular bacterial load. J Infect Dis 2003, 188:1119-1131.

68. LeVine AM, Whitsett JA, Gwozdz JA, Richardson TR, Fisher JH, Burhans MS, Korfhagen TR: Distinct effects of surfactant protein A or D deficiency during bacterial infection on the lung. I Immunol 2000, 165:3934-3940.

69. Dessing MC, van der Sluijs KF, Florquin S, Akira S, van der Poll T: Toll-like receptor 2 does not contribute to host response during postinfluenza pneumococcal pneumonia. Am J Respir Cell Mol Biol 2007, 36:609-614.

70. Dessing MC, Florquin S, Paton JC, van der Poll T: Toll-like receptor 2 contributes to antibacterial defence against pneumolysin-deficient pneumococci. Cell Microbio/ 2008, 10:237-246.

71. Hussell T, Cavanagh MM: The innate immune rheostat: influence on lung inflammatory disease and secondary bacterial pneumonia. Biochem Soc Trans 2009, 37:811-813.

72. Fallarino F, Asselin-Paturel C, Vacca C, Bianchi R, Gizzi S, Fioretti MC, Trinchieri G, Grohmann U, Puccetti P: Murine plasmacytoid dendritic cells initiate the immunosuppressive pathway of tryptophan catabolism in response to CD200 receptor engagement. J Immunol 2004, 173:3748-3754

73. Rothberg MB, Haessler SD, Brown RB: Complications of viral influenza. Am J Med 2008, 121:258-264

74. Xia Z, Jin G, Zhu J, Zhou R: Using a mutual information-based site transition network to map the genetic evolution of influenza $\mathrm{A} / \mathrm{H} 3 \mathrm{~N} 2$ virus. Bioinformatics 2009, 25:2309-2317.

75. Smith GJ, Vijaykrishna D, Bahl J, Lycett SJ, Worobey M, Pybus OG, Ma SK, Cheung CL, Raghwani J, Bhatt S, Peiris JS, Guan Y, Rambaut A: Origins and evolutionary genomics of the 2009 swine-origin H1N1 influenza A epidemic. Nature 2009, 459:1122-1125.

76. von Itzstein M, Wu WY, Kok GB, Pegg MS, Dyason JC, Jin B, Van Phan T, Smythe ML, White HF, Oliver SW, Colman PM, Varghese JN, Ryan DM, Woods JM, Bethell RC, Hotham VJ, Cameron ${ }^{\S}$ JM, Penn CR: Rational design of potent sialidase-based inhibitors of influenza virus replication. Nature 1993 363:418-423.

77. Kim CU, Lew W, Williams MA, Liu H, Zhang L, Swaminathan S, Bischofberger $\mathrm{N}$, Chen MS, Mendel DB, Tai CY, Laver WG, Stevens RC: Influenza neuraminidase inhibitors possessing a novel hydrophobic interaction in the enzyme active site: design, synthesis, and structural analysis of carbocyclic sialic acid analogues with potent anti-influenza activity. J Am Chem Soc 1997, 119:681-690.

78. Davies WL, Grunert RR, Haff RF, Mcgahen JW, Neumayer EM, Paulshock M, Watts JC, Wood TR, Hermann EC, Hoffmann CE: Antiviral activity of 1-Adamantanamine (Amantadine). Science 1964, 144:862-863.

79. Ruf BR, Szucs T: Reducing the burden of influenza-associated complications with antiviral therapy. Infection 2009, 37:186-196.

80. Crusat M, de Jong MD: Neuraminidase inhibitors and their role in avian and pandemic influenza. Antivir Ther 2007, 12:593-602.

81. Mandell LA, Wunderink RG, Anzueto A, Bartlett JG, Campbell GD, Dean NC, Dowell SF, File TM Jr, Musher DM, Niederman MS, Torres A, Whitney CG; Infectious Diseases Society of America; American Thoracic Society: Infectious Diseases Society of America/American Thoracic Society consensus guidelines on the management of community-acquired pneumonia in adults. Clin Infect Dis 2007, 44:S27-S72.

82. Karlström A, Boyd KL, English BK, McCullers JA: Treatment with protein synthesis inhibitors improves outcomes of secondary bacterial pneumonia after influenza. J Infect Dis 2009, 199:311-319.

83. Yamaryo T, Oishi K, Yoshimine H, Tsuchihashi Y, Matsushima K, Nagatake T: Fourteen-member macrolides promote the phosphatidylserine receptordependent phagocytosis of apoptotic neutrophils by alveolar macrophages. Antimicrob Agents Chemother 2003, 47:48-53.

84. Laterre PF, Garber G, Levy H, Wunderink R, Kinasewitz GT, Sollet JP, Maki DG, Bates B, Yan SC, Dhainaut JF; PROWESS Clinical Evaluation Committee: Severe community-acquired pneumonia as a cause of severe sepsis: data from the PROWESS study. Crit Care Med 2005, 33:952-961.

doi:10.1186/cc8893

Cite this article as: van der Sluijs KF, et al.: Bench-to-bedside review:

Bacterial pneumonia with influenza - pathogenesis and clinical implications. Critical Care 2010, 14:219. 